\title{
PENAPISAN DAN OPTIMASI PERTUMBUHAN BAKTERI LAUT YANG BERPOTENSI SEBAGAI HIDROKARBONOKLASTIK PAH FENOTIAZIN
}

\section{Screening and Growth Optimization of Potential Marine Bacteria as Hydrocarbonoclastic of Phenothiazine PAH}

\author{
Elvi Yetti*, Ahmad Thontowi dan Yopi \\ Pusat Penelitian Bioteknologi, Lembaga IImu Pengetahuan Indonesia (LIPI), Komplek CSC-LIPI, \\ Jalan Raya Bogor KM. 46, Cibinong, Bogor, Jawa Barat \\ * Korespondensi Penulis: eti.lipi@gmail.com \\ Diterima: 9 Juli 2016; Disetujui: 12 Nopember 2016
}

\begin{abstract}
ABSTRAK
Fenotiazin merupakan senyawa dari kelompok hidrokarbon aromatik polisiklik atau polycyclic aromatic hydrocarbon (PAH) yang terkandung di dalam minyak mentah. Fenotiazin bersifat persisten dan mudah terbakar di lingkungan. Selain itu fenotiazin juga menyebabkan iritasi kulit, hepatitis, dan anemia terhadap manusia. Bakteri laut memiliki kemampuan untuk mendegradasi senyawa $\mathrm{PAH}$. Tujuan penelitian ini adalah menyeleksi bakteri laut yang berpotensi sebagai hidrokarbonoklastik fenotiazin dan melakukan optimasi konsentrasi fenotiazin untuk studi biodegradasinya. Seleksi isolat dilakukan pada media padat dengan metoda sublimasi dan media cair dengan uji pertumbuhan. Hasil seleksi awal dengan metoda sublimasi menunjukkan 32 isolat sebagai kandidat bakteri pendegradasi fenotiazin. Isolat-isolat ini dikelompokkan menjadi 3 kelompok berdasarkan indikatornya dalam seleksi dengan media padat yaitu isolat yang dapat mengubah warna media, membentuk zona bening, dan isolat yang memiliki kemampuan keduanya. Seleksi dengan menggunakan uji pertumbuhan menunjukkan bahwa isolat LBF-10057 yang teridentifikasi sebagai Pseudomonas aeruginosa strain MCCB102 dan isolat LBF-10126 memiliki pertumbuhan terbaik dari kelompok isolat yang mengubah warna media. Isolat LBF-1-0102 yang teridentifikasi sebagai Pseudomonas balerica BerOc6 dan isolat LBF-1-0133 yang teridentifikasi sebagai $P$. aeruginosa ATCC10145 merupakan isolat terbaik dari kelompok zona bening, sedangkan isolat LBF-1-0115 adalah isolat dengan pertumbuhan tertinggi di kelompok berindikator keduanya. Konsentrasi optimum fenotiazin untuk $P$. aeruginosa strain MCCB102, P. aeruginosa ATCC10145, dan isolat LBF-1-0115 adalah 500 ppm; sedangkan 250 ppm merupakan konsentrasi optimum untuk isolat LBF-1-0126 dan P. balerica BerOc6.
\end{abstract}

KATA KUNCI : bakteri laut, hidrokarbonoklastik fenotiazin, optimasi konsentrasi

\section{ABSTRACT}

Phenotiazine is one compound of polycyclic aromatic hydrocarbon (PAH) containing in crude oil. Phenothiazine is persistent and combustible. In addition, it leads to skin irritation, hepatitis, and anemia. Marine bacteria are potential for PAH degradation. The aims of this research are to select marine bacteria that are potential for hydrocabonoclastic phenothiazine and to optimize substrate concentration for biodegradation study. Isolates selection was carried out on solid medium by sublimation method and broth medium by growth test. Result of initial selection by sublimation method showed that 32 potential isolates as candidates of phenothiazine degrading bacteria. These isolates were classified into 3 (three) groups according to their indicator in selection process by solid medium namely isolates which could change medium color, isolates that could form clear zones, and isolate which had both of those indicators, respectively. Selection by growth test revealed that isolate LBF-1-0057 identified as Pseudomonas aeruginosa strain MCCB 102 and isolate LBF-1-0126 had the highest growth from isolates that changed the medium color. Isolates LBF-1-0102 known as Pseudomonas balerica BerOc6 and isolate LBF-1-0133 as $\underline{P}$. aeruginosa ATCC10145 were the best isolates from clear zone group, while LBF-1-0115 was isolate with the highest growth in the group that showed both of those indicators. Optimal concentration of pheniothiazine of isolates $\underline{\underline{P}}$ aeruginosa strain MCCB 102, $\underline{P}$. aeruginosa ATCC, and isolate LBF1-0115 was 500 ppm; whereas, 250 ppm was optimal concentration of isolates LBF-1-0126 and P. balerica BerOc6.

KEYWORDS: $\quad$ marine bacteria, hydrocarbonoclastic phenotiazine, optimization of concentration

Copyright @ (2016, JPBKP, Nomor Akreditasi : 573/AU2/P2MI-LIPI/07/2014 


\section{PENDAHULUAN}

Pencemaran minyak mentah di wilayah laut semakin meningkat seiring dengan meningkatnya konsumsi dan produksi minyak mentah dari tahun ke tahun. Pencemaran ini berasal dari aktivitas transportasi pengiriman minyak mentah dan limbah industri. Pencemaran minyak mentah sangat berbahaya bagi ekosistem laut karena tersusun dari senyawa-senyawa hidrokarbon kompleks yang salah satunya adalah PAH/ Polycyclic Aromatic Hydrocarbon (Pampanin \& Sydnes 2013).

Senyawa PAH tergolong sebagai senyawa beracun, mutagenik, dan karsinogenik. Keberadaan senyawa PAH di lautan akan mengancam kehidupan organisme laut, karena dapat menyebabkan tumor, kanker dan kehilangan kemampuan sublethal respon. Senyawa PAH dengan kadar 50-1000 $\mu \mathrm{g} / \mathrm{l}$ di lautan, menyebabkan keracunan akut pada organisme laut dan senyawa PAH sebesar $0,1-0,5 \mu \mathrm{g} / \mathrm{l}$ dapat menghilangkan sublethal respon organisme laut. Kandungan $\mathrm{PAH}$ pada lautan diperkirakan mencapai 230.000 ton (Eisler, 1987; Mrozik, Piotrowska-Seget, \& Labuzek 2003). Untuk mendegradasi senyawa PAH biasanya dilihat dari berat molekulnya. Senyawa PAH dengan berat molekul yang tinggi lebih bersifat hidrofobik dan memiliki struktur yang lebih kompleks sehingga bioavailability mikroorganisme untuk mendegradasi senyawa PAH menurun (Mrozik et al., 2003). Berat molekul juga dapat menentukan tingkat toksisitas dari senyawa PAH.

Bakteri laut memiliki kemampuan untuk mendegradasi senyawa PAH. Kemampuan bakteri laut dalam mendegradasi senyawa PAH bergantung pada kondisi lingkungannya, berupa $\mathrm{pH}$, temperatur, oksigen dan sumber nutrien. Selain itu kemampuan mendegradasi senyawa PAH ditentukan juga oleh jumlah bakteri, kemampuan transportasi selular dan struktur dari senyawa PAH. Struktur senyawa PAH dengan berat molekul yang tinggi akan sulit untuk didegradasi. Hal ini disebabkan menurunnya kelarutan senyawa $\mathrm{PAH}$ dalam air sehingga menurunkan bioavailability mikroorganisme untuk mencernanya (Haritash \& Kaushik 2009).

Penelitian tentang bakteri laut yang potensial untuk mendegradasi senyawa PAH telah banyak dilaporkan. Beberapa genus bakteri laut diketahui dapat menggunakan PAH sebagai sumber seperti Marinobacter dan Vibrio (Hedlund \& Staley, 2001); Pseudoalteromonas, Marinomonas dan Halomonas (Melcher, Apitz, \& Hemmingsen, 2002); Sphingomonas (Demaneche et al., 2004) dan Pseudoalteromonas (Hedlund \& Staley, 2006). Beberapa peneliti di Indonesia juga melaporkan tentang bakteri laut pendegradasi senyawa PAH. Bakteri pendegradasi PAH yakni Alteromonas alvinellae Bt05, sebelumnya telah diisolasi dari Teluk Jakarta, Indonesia (Thontowi \& Yopi, 2013). Tanning et al. (2016) melaporkan bahwa bakteri laut yang teridentifikasi sebagai Novosphingobium mathurense memiliki kemampuan mendegradasi senyawa dibenzotiofen. Bakteri ini sebelumnya diperoleh dari perairan laut Muara Kamal, Teluk Jakarta, Indonesia. Keanekaragaman bakteri laut yang diisolasi dari beberapa perairan di Indonesia dalam mendegradasi senyawa PAH selanjutnya dilaporkan oleh Yetti, Thontowi \& Yopi (2016).

Studi mikrobial terkait bakteri pendegradasi fenotiazin menjadi menarik karena senyawa ini dan turunannya banyak digunakan untuk aplikasi kesehatan terutama untuk terapi penyakit kanker. Di samping itu, studi terkait degradasi fenotiazin belum banyak dilaporkan. Fenotiazin merupakan salah satu senyawa $\mathrm{PAH}$, terdapat dalam minyak mentah, dan berfungsi sebagai antioksidan dan penstabil dengan berat molekul 199 (Gambar 1). Fenotiazin merupakan senyawa yang mudah teroksidasi, dapat terbakar dan akan menghasilkan

\section{Phenothiazine}

[92-84-2]

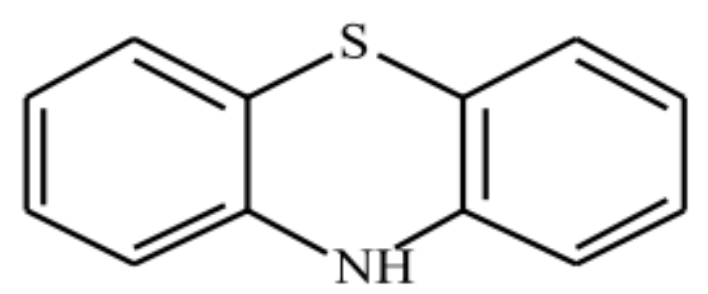

Gambar 1. Struktur Molekul Fenotiazin (Sumber: Jaszczyszyn et al., 2012)

Figure 1. Molecular Structure of Phenothiazine (Source: Jaszczyszyn et al., 2012) 
gas yang sangat beracun, yaitu gas sulfur dan nitrogen oksida.

Riset sebelumnya lebih banyak melakukan studi tentang isolasi dan seleksi bakteri pendegradasi senyawa polycyclic aromatic hydrocarbon (PAH), yang salah satunya adalah fenotiazin. Lisdiyanti, Yopi dan Murniasih (2011) melakukan skrining terhadap bakteri laut dari Pantai Marina, Ancol,Teluk Jakarta dan mendapatkan 14 strain positif terhadap fenotiazin. Sebelumnya, kami juga melakukan skrining, identifikasi, dan penentuan biodiversitas bakteri pendegradasi $\mathrm{PAH}$ terhadap 132 isolat bakteri laut dari beberapa perairan Indonesia seperti Pulau Pari, Muara Kamal, dan Pantai Cilacap, Jawa Tengah. Dari 58 bakteri potensial sebagai pendegradasi PAH, 25 isolat di antaranya berpotensi sebagai pendegradasi fenotiazin (Yetti et al., 2016). Skrining lanjutan yang dilakukan mendapatkan 8 isolat bakteri laut yang potensial sebagai pendegradasi fenotiazin dan belum dipublikasikan. Dari 33 isolat yang berpotensi sebagai hidrokarbonoklastik fenotiazin, sebanyak 32 isolat berhasil diremajakan dan ditumbuhkan kembali. Selanjutnya kami ingin menyeleksi dan mengidentifikasi lanjut isolat-isolat bakteri laut yang potensial ini untuk memilih isolat unggul untuk studi biodegradasi fenotiazin. Fokus penelitian ini adalah seleksi bakteri laut yang berpotensi mendegradasi fenotiazin dan optimasi konsentrasi substrat yakni fenotiazin untuk studi biodegradasinya.

\section{BAHAN DAN METODE}

Bahan yang digunakan meliputi Marine Broth dari BD Difco 2216, Pure Agar, artificial sea water (ASW) Marine dari art®SF-1, double distilled water $\left(\mathrm{dd}_{2} \mathrm{O}\right)$, larutan stok fenotiazin (3000 ppm), dan Buffer fosfat $0,2 \mathrm{M}, \mathrm{pH} 7,0$.

Alat-alat yang digunakan adalah spektrofotometer UV-VIS, deep well, autoklaf, freezer, shaker, inkubator, sentrifus, microwave, laminar air flow, penangas air, tabung eppendorf 1,5 mL, termometer, neraca analitik, pipet mikro, dan seperangkat alat gelas lainnya

\section{Mikroorganisme dan Media}

Isolat yang digunakan adalah 32 isolat potensial sebagai kandidat pendegradasi fenotiazin dan merupakan koleksi Laboratorium Biokatalis dan Fermentasi, Puslit Bioteknologi LIPI. Isolat-isolat tersebut sebelumnya diisolasi dari beberapa perairan laut di Indonesia yakni Pulau Pari, Muara Kamal, dan Pantai Cilacap, Jawa Tengah (Thontowi \& Yopi, 2013; Yopi, Theresia, Thontowi, \& Susilaningsih, 2006). Isolat diremajakan dengan media Marine Agar (MA) dan diinkubasi selama 24 jam dengan suhu
$30{ }^{\circ} \mathrm{C}$. Untuk uji pertumbuhan dan biodegradasi, isolat dikultur di dalam media artificial sea water (ASW) cair.

Hasil penapisan awal dengan metoda sublimasi seperti dilaporkan oleh Yetti et al. (2016) menunjukkan bahwa 24 isolat di antara 32 isolat tersebut berpotensi sebagai kandidat bakteri laut pendegradasi fenotiazin. Uji sublimasi yang dilakukan selanjutnya juga menunjukkan bahwa 8 isolat lain berpotensi sebagai pendegradasi fenotiazin. Daftar isolat dan indikator sublimasi diperlihatkan pada Tabel 1.

\section{Seleksi isolat yang Berpotensi sebagai Hidrokarbonoklastik Fenotiazin}

Seleksi isolat potensial sebagai hidrokarbonoklastik fenotiazin dilakukan dengan uji pertumbuhan yang dilakukan dalam deepwell yang berisi 50 ppm fenotiazin, media cair ASW dan isolat bakteri laut dengan penyetaraan nilai OD600nm adalah 1. Total volume dalam deepwell sebanyak 1 $\mathrm{ml}$. Kultur dalam deepwell dimasukkan ke deepwell shaker pada suhu $30^{\circ} \mathrm{C}$ pada kecepatan $1500 \mathrm{rpm}$ selama 7 hari. Sampling untuk mengetahui pertumbuhan bakteri dilakukan pada hari ke 0 dan hari ke 7 dengan mengukur OD pada panjang gelombang $600 \mathrm{~nm}$.

\section{Produksi Sel}

Produksi sel dilakukan dengan sentrifugasi kultur bakteri dengan kecepatan $6000 \mathrm{rpm}$, pada suhu $4^{\circ} \mathrm{C}$ selama 10 menit dan dilakukan menggunakan botol falcon berukuran $50 \mathrm{ml}$. Hasil dari sentrifugasi berupa pelet kemudian dilarutkan menggunakan bufer fosfat 0,2 M dengan $\mathrm{pH} 7,0$ sebanyak $3 \mathrm{~mL}$ dan diukur optical dencity (OD) menggunakan spektrofotometer dengan pengenceran 300x.

\section{Optimasi Konsentrasi Fenotiazin}

Optimasi konsentrasi fenotiazine dilakukan dengan menumbuhkan sel bakteri dengan OD 1, media ASW dan fenotiazin dengan konsentrasi beragam $(0,50$, 100, 250 dan 500 ppm) dalam deepwell dengan volume $1 \mathrm{ml}$. Deepwell diinkubasi di dalam deepwell shaker pada suhu $30^{\circ} \mathrm{C}$ dengan kecepatan $1500 \mathrm{rpm}$ selama 7 hari dan dilakukan sampling pada hari ke 0 dan hari ke 7 menggunakan spektramax $\AA$ paradigm $\AA$ dengan pengenceran $4 x$ (untuk hari ke 0 ) dan 10x (untuk hari ke 7).

\section{Identifikasi Isolat Bakteri dengan Analisis Gen Parsial 16SRNA}

Isolat terpilih untuk optimasi biodegradasi fenotiazin diidentifikasi berdasarkan analisis sebagian gen $16 \mathrm{~S}$ rRNA. Ekstraksi, isolasi dan purifikasi DNA bakteri menggunakan PCR Mix Go Taq MM Green 
Tabel 1. Daftar Isolat Bakteri Laut Pendegradasi Fenotiazin yang Digunakan dalam Penelitian Ini Table 1. Isolates List of Marine Phenothiazine Degrading Bacteria Used in this Study

\begin{tabular}{|c|c|}
\hline $\begin{array}{l}\text { Kode Koleksi/ } \\
\text { Isolates code }\end{array}$ & $\begin{array}{l}\text { Hasil Skrining Awal dengan Metoda Sublimasi/ } \\
\text { First screening result with sublimation method }\end{array}$ \\
\hline LBF-1-0001 & Mengubah warna media/Change medium color (Yetti et al., 2016) \\
\hline LBF-1-0003 & Mengubah warna media/Change medium color (Yetti et al., 2016) \\
\hline LBF-1-0020 & Mengubah warna media/Change medium color (Yetti et al., 2016) \\
\hline LBF-1-0040 & Mengubah warna media/Change medium color (Yetti et al., 2016) \\
\hline LBF-1-0046 & Mengubah warna media/Change medium color (Yetti et al., 2016) \\
\hline LBF-1-0050 & Mengubah warna media/Change medium color (Yetti et al., 2016) \\
\hline LBF-1-0056 & Mengubah warna media/Change medium color (Yetti et al., 2016) \\
\hline LBF-1-0057 & Mengubah warna media/Change medium color (Yetti et al., 2016) \\
\hline LBF-1-0062 & Mengubah warna media/Change medium color (Yetti et al., 2016) \\
\hline LBF-1-0074 & Mengubah warna media/Change medium color (Yetti et al., 2016) \\
\hline LBF-1-0103 & Mengubah warna media/Change medium color (Yetti et al., 2016) \\
\hline LBF-1-0104 & Mengubah warna media/Change medium color (data belum terpublikasi/unpublished) \\
\hline LBF-1-0107 & Mengubah warna media/Change medium color (Yetti et al., 2016) \\
\hline LBF-1-0109 & Mengubah warna media/Change medium color (data belum terpublikasi/unpublished) \\
\hline LBF-1-0111 & Mengubah warna media/Change medium color (Yetti et al., 2016) \\
\hline LBF-1-0113 & Mengubah warna media/Change medium color (data belum terpublikasi/unpublished) \\
\hline LBF-1-0117 & Mengubah warna media/Change medium color (data belum terpublikasi/unpublished) \\
\hline LBF-1-0118 & Mengubah warna media/Change medium color (Yetti et al., 2016) \\
\hline LBF-1-0124 & Mengubah warna media/Change medium color (Yetti et al., 2016) \\
\hline LBF-1-0125 & Mengubah warna media/Change medium color (Yetti et al., 2016) \\
\hline LBF-1-0126 & Mengubah warna media/Change medium color (data belum terpublikasi/unpublished) \\
\hline LBF-1-0102 & Membentuk zona bening/Form the clear zone (Yetti et al., 2016) \\
\hline LBF-1-0114 & Membentuk zona bening/Form the clear zone (Yetti et al., 2016) \\
\hline LBF-1-0127 & Membentuk zona bening/Form the clear zone (data belum terpublikasi/unpublished) \\
\hline LBF-1-0129 & Membentuk zona bening/Form the clear zone (Yetti et al., 2016) \\
\hline LBF-1-0130 & Membentuk zona bening/Form the clear zone (Yetti et al., 2016) \\
\hline LBF-1-0133 & Membentuk zona bening/Form the clear zone (Yetti et al., 2016) \\
\hline LBF-1-0136 & Membentuk zona bening/Form the clear zone (Yetti et al., 2016) \\
\hline LBF-1-0138 & Membentuk zona bening/Form the clear zone (data belum terpublikasi/unpublished) \\
\hline LBF-1-0143 & Membentuk zona bening/Form the clear zone (Yetti et al., 2016) \\
\hline LBF-1-0022 & $\begin{array}{l}\text { Mengubah warna media dan membentuk zona bening/Change medium color and form the } \\
\text { clear zone (Yetti et.al., 2016) }\end{array}$ \\
\hline LBF-1-0115 & $\begin{array}{l}\text { Mengubah warna media dan membentuk zona bening/Change medium color and form the } \\
\text { clear zone (data belum terpublikasi/unpublished) }\end{array}$ \\
\hline
\end{tabular}

PROMEGA. Primer yang digunakan adalah primer 9 F (5'-GAGTTTGATCCTGGCTCAG-3') dan 1510 R (5'GCTACCTTGTTACGACTT-3'). Kondisi reaksi PCR adalah $95^{\circ} \mathrm{C} 2$ menit (1 siklus), $95^{\circ} \mathrm{C} 30$ detik, $65^{\circ} \mathrm{C}$ 1 menit, $72{ }^{\circ} \mathrm{C} 2$ menit (10 siklus); $95^{\circ} \mathrm{C} 30$ detik, $55^{\circ} \mathrm{C} 1$ menit, $72{ }^{\circ} \mathrm{C} 2$ menit (30 siklus) (Thontowi dan Yopi, 2013). Hasil amplifikasi kemudian dipurifikasi dan disekuensing. Analisis urutan nukleotida menggunakan program BLAST berdasarkan bank data. Pembuatan pohon filogenetik dilakukan dengan menggunakan software MEGA 5.0. 


\section{HASIL DAN PEMBAHASAN}

\section{Hasil Seleksi Isolat Kandidat Bakteri yang Berpotensi sebagai Hidrokarbonoklastik Fenotiazin}

Berdasarkan indikator pada skrining awal, 32 isolat potensial pendegradasi fenotiazin dibedakan menjadi 3 kelompok yakni 1) isolat yang dapat mengubah warna media menjadi biru (21 isolat);
2) isolat yang dapat membentuk zona bening (9 isolat); dan 3) isolat yang memiliki kemampuan keduanya (2 isolat). Salah satu indikator positif dalam penapisan senyawa PAH ditunjukkan oleh adanya perubahan warna media (Stieber, Haeseler, Werner, \& Frimme, 1994; Wrenn \& Venosa, 1996). Pada penelitian ini isolat yang berpotensi sebagai bakteri pendegradasi fenotiazin dapat mengubah media baik padat maupun cair menjadi warna biru (data tidak ditunjukkan). Indikator lainnya adalah terbentuknya

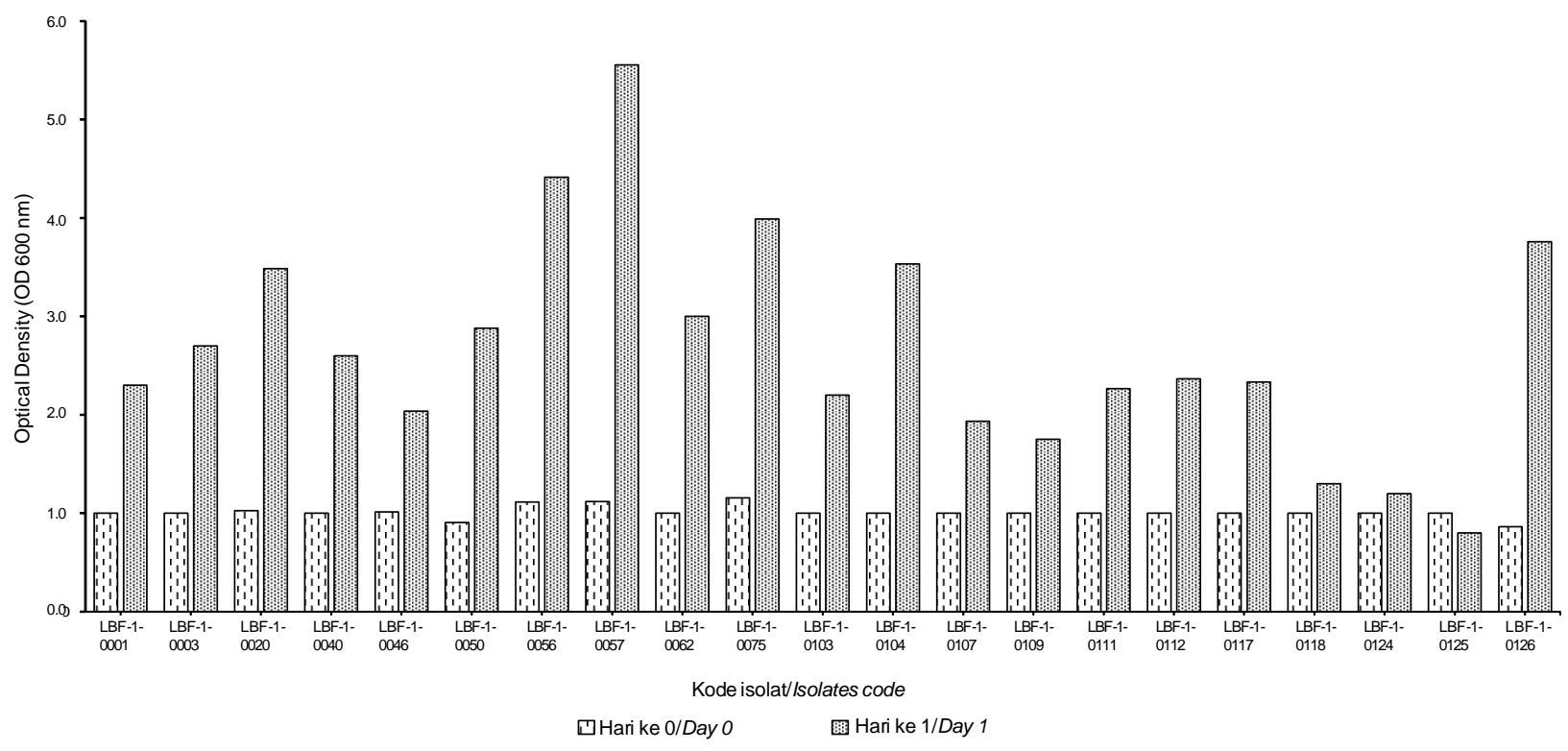

Gambar 2. Hasil seleksi uji pertumbuhan isolat yang berpotensi sebagai hidrokarbonoklastik fenotiazin dari kelompok yang mengubah warna media.

Figure 2. Results of selection of potential phenothiazine hydrocarbonoclastic isolates by growth test from colour change group

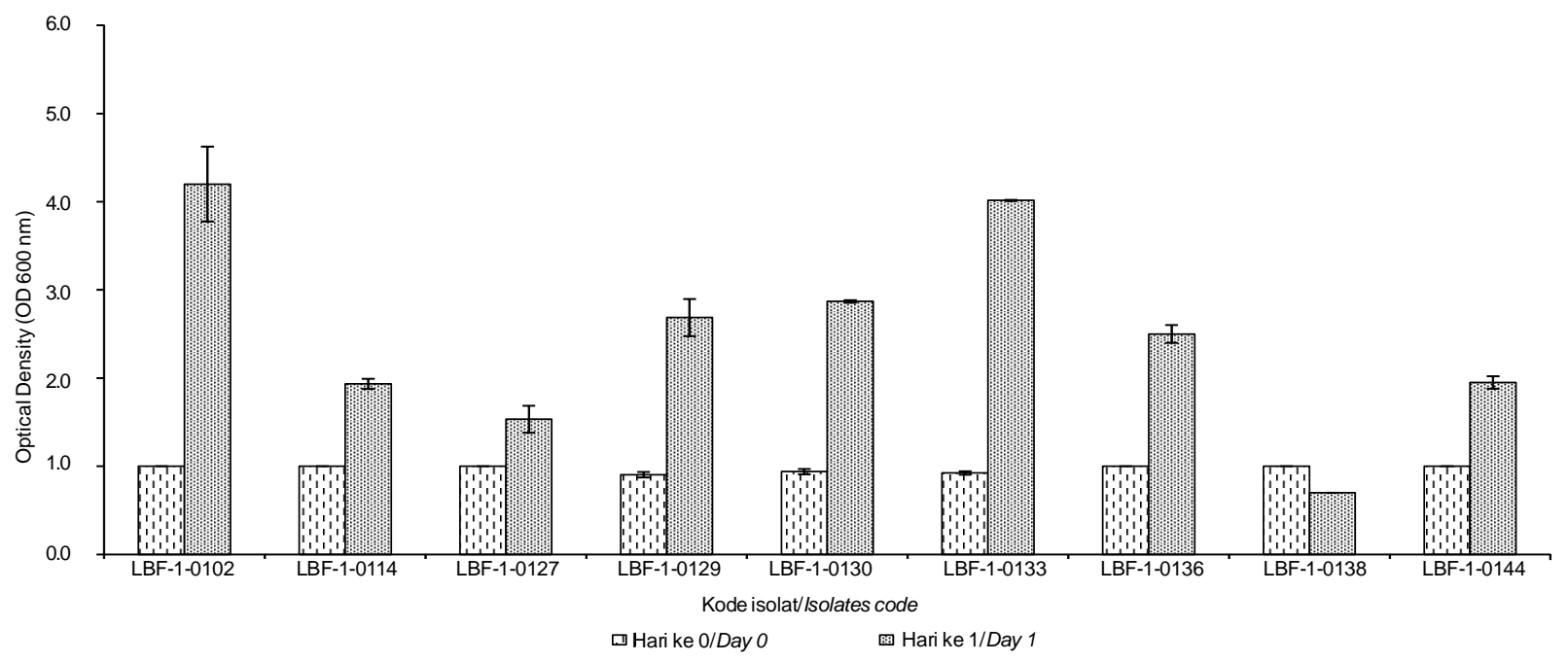

Gambar 3. Hasil seleksi uji pertumbuhan isolat yang berpotensi sebagai hidrokarbonoklastik fenotiazin dari kelompok yang membentuk zona bening.

Figure 3. Results of selection of potential phenothiazine hydrocarbonoclastic isolates by growth test from clear zone group. 


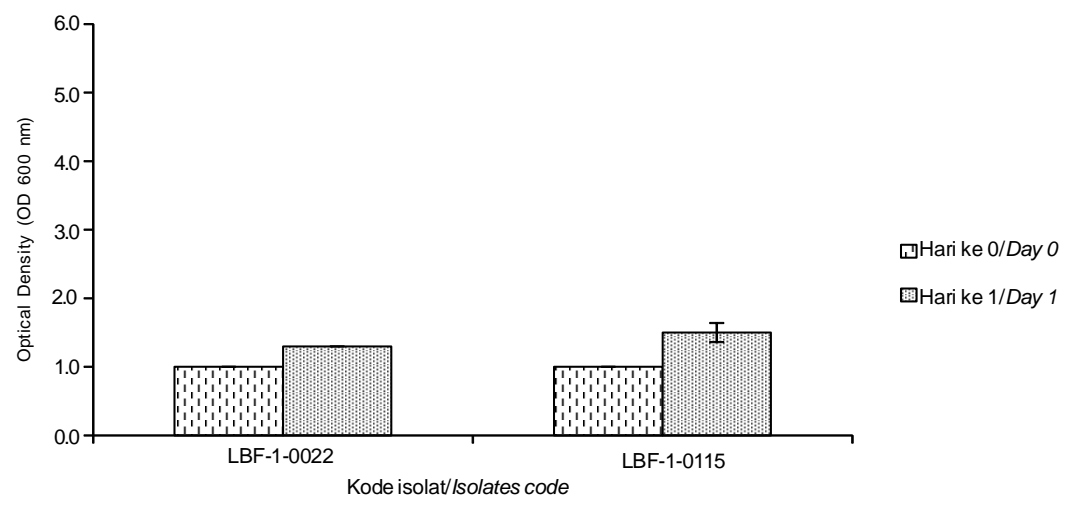

Gambar 4. Hasil seleksi uji pertumbuhan isolat berpotensi sebagai hidrokarbonoklastik fenotiazin dari kelompok yang mampu mengubah warna media dan membentuk zona bening,

Figure 4. Results of selection of potential phenothiazine hydrocarbonoclastic isolates by growth test from isolates capable of changing medium colour and forming clear zone group.

zona bening di sekitar isolat (Kastner, Breuer-Jammali, \& Mahro, 1994; Kiyohara, Nagao, \& Yana, 1982).

Hasil seleksi isolat berdasarkan kelompoknya ditunjukkan pada Gambar 2, 3, dan 4. Gambar 2 menunjukkan bahwa dari kelompok isolat yang dapat mengubah warna media terdapat 3 isolat dengan pertumbuhan terbaik yakni isolat LBF-1-0056, LBF1-0057, dan LBF-1-0126. Isolat LBF-1-0057 merupakan isolat dengan pertumbuhan tertinggi dengan inkubasi selama 7 hari.

Hasil seleksi isolat potensial sebagai hidrokarbonoklastik fenotiazin dari kelompok isolat yang dapat membentuk zona bening menunjukkan bahwa isolat LBF-1-0102 dan LBF-1-0133 memiliki pertumbuhan yang paling baik. Isolat LBF-1-0103 merupakan isolat dengan pertumbuhan tertinggi (Gambar 3).

Sebanyak 2 dari 32 isolat potensial pendegradasi fenotiazin yakni LBF-1-0022 dan LBF-1-0115 menunjukkan indikasi dapat mengubah warna dan membentuk zona bening pada media padat. Hasil uji pertumbuhan ke 2 isolat dalam media ASW cair yang mengandung fenotiazin 50 ppm menunjukkan bahwa isolat LBF-1-0115 memiliki pertumbuhan lebih tinggi dibandingkan isolat LBF-1-0022.

Sebanyak 6 isolat dari total 32 isolat terpilih sebagai isolat yang unggul pertumbuhannya dalam media yang mengandung fenotiazin sebagai substrat yakni LBF-1-0056, LBF-1-0057, LBF-1-0126, LBF-10102, LBF-1-0133, dan LBF-1-0115. Hal ini menunjukkan bahwa isolat-isolat tersebut paling maksimal memanfaatkan fenotiazin sebagai substrat atau sumber karbon untuk pertumbuhannya di antara isolat lain di kelompoknya masing-masing. Salah satu faktor yang mempengaruhi pertumbuhan isolat bakteri dalam suatu media adalah nutrisi dan substrat yang tersedia dalam media tersebut. Bila nutrisi dan substrat cocok untuk pertumbuhannya, maka bakteri akan dapat tumbuh dengan baik. Fenotiazin sebagai substrat merupakan salah satu senyawa PAHs yang sebenarnya bersifat toksik bagi mikroorganisme (Francy, Thomas, Raymond, \& Ward, 1991). Hanya mikroorganisme atau bakteri tertentu saja yang dapat menggunakannya sebagai sumber karbon. Di samping itu, kemampuan isolat bakteri dalam mengkonsumsi PAHs juga dipengaruhi oleh kemampuan adaptasi yang tinggi terhadap adanya PAHs. Hal ini pula yang menunjukkan bawa isolatisolat bakteri laut yang terpilih memiliki kemampuan adaptasi yang baik terhadap keberadaan PAHs di dalam media tumbuhnya.

\section{Hasil Optimasi Konsentrasi Fenotiazin}

Optimasi konsentrasi fenotiazin dilakukan untuk melihat efektifitas pertumbuhan isolat pendegradasi fenotiazin. Pengamatan optimasi dilakukan per kelompok isolat terpilih. Pada kelompok isolat yang memiliki kemampuan mengubah warna media diwakili oleh isolat LBF-1-0056, LBF-1-0057, dan LBF-1-0126. $\mathrm{Di}$ antara 3 isolat tersebut, terlihat bahwa 2 isolat pertama dapat tumbuh hingga konsentrasi fenotiazin 500 ppm. Isolat-isolat ini bahkan dapat optimal pada fenotiazin dengan konsentrasi 500 ppm tersebut. Berbeda dengan isolat LBF-1-0126 yang optimal pertumbuhannya pada konsentrasi fenotiazin 250 ppm (Gambar 5).

Pada kelompok isolat yang memiliki kemampuan dapat membentuk zona bening, isolat LBF-1-0102 dan LBF-1-0133 terlihat dapat tumbuh dalam media yang mengandung fenotiazin hingga konsentrasi 500 ppm. Namun untuk tumbuh optimal masing-masing isolat 

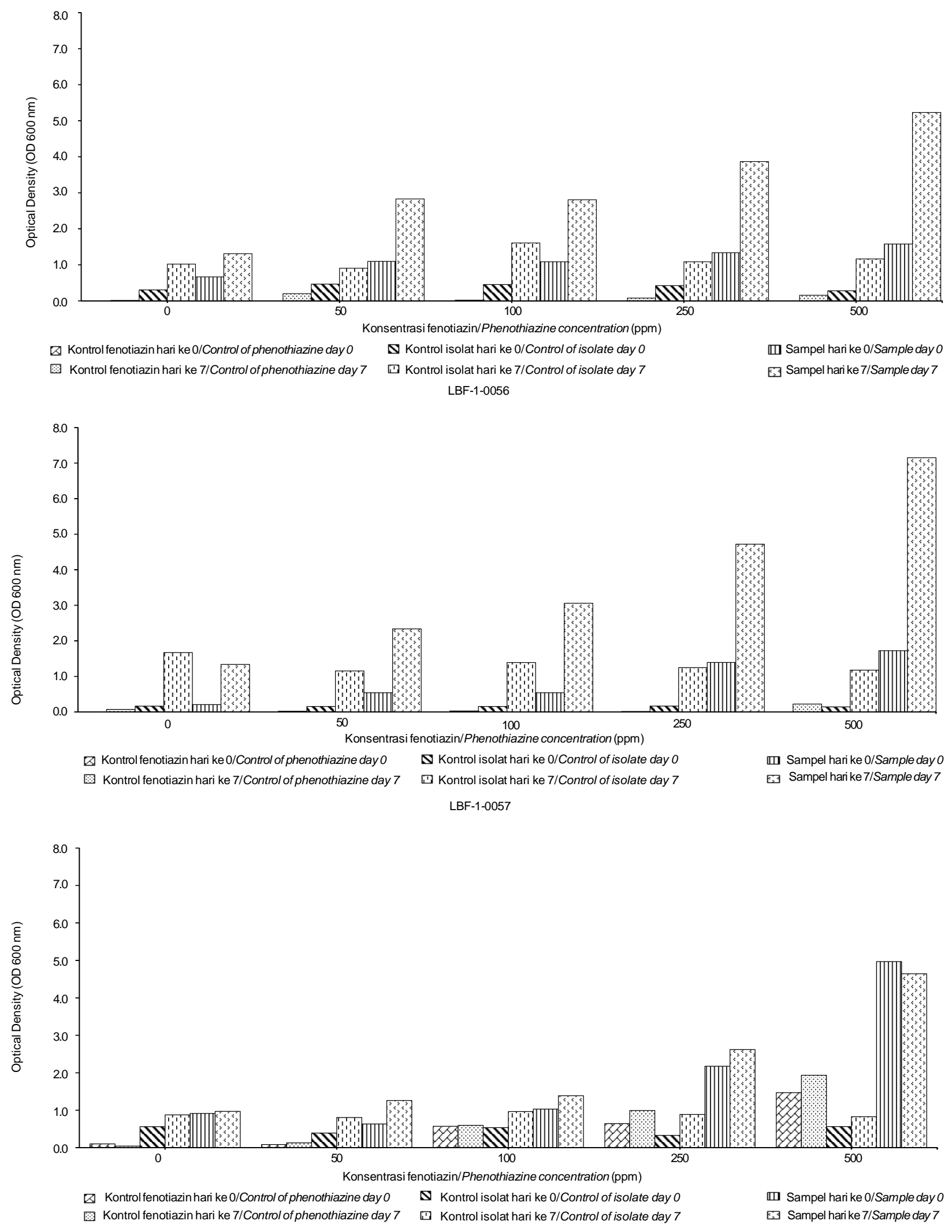

Gambar 5 . Hasil optimasi konsentrasi fenotiazin dari 3 isolat terpilih kelompok yang mampu mengubah warna media

Figure 5. Results of optimization of phenothiazine concentration from 3 (three) selected isolates capable of changing medium colour 

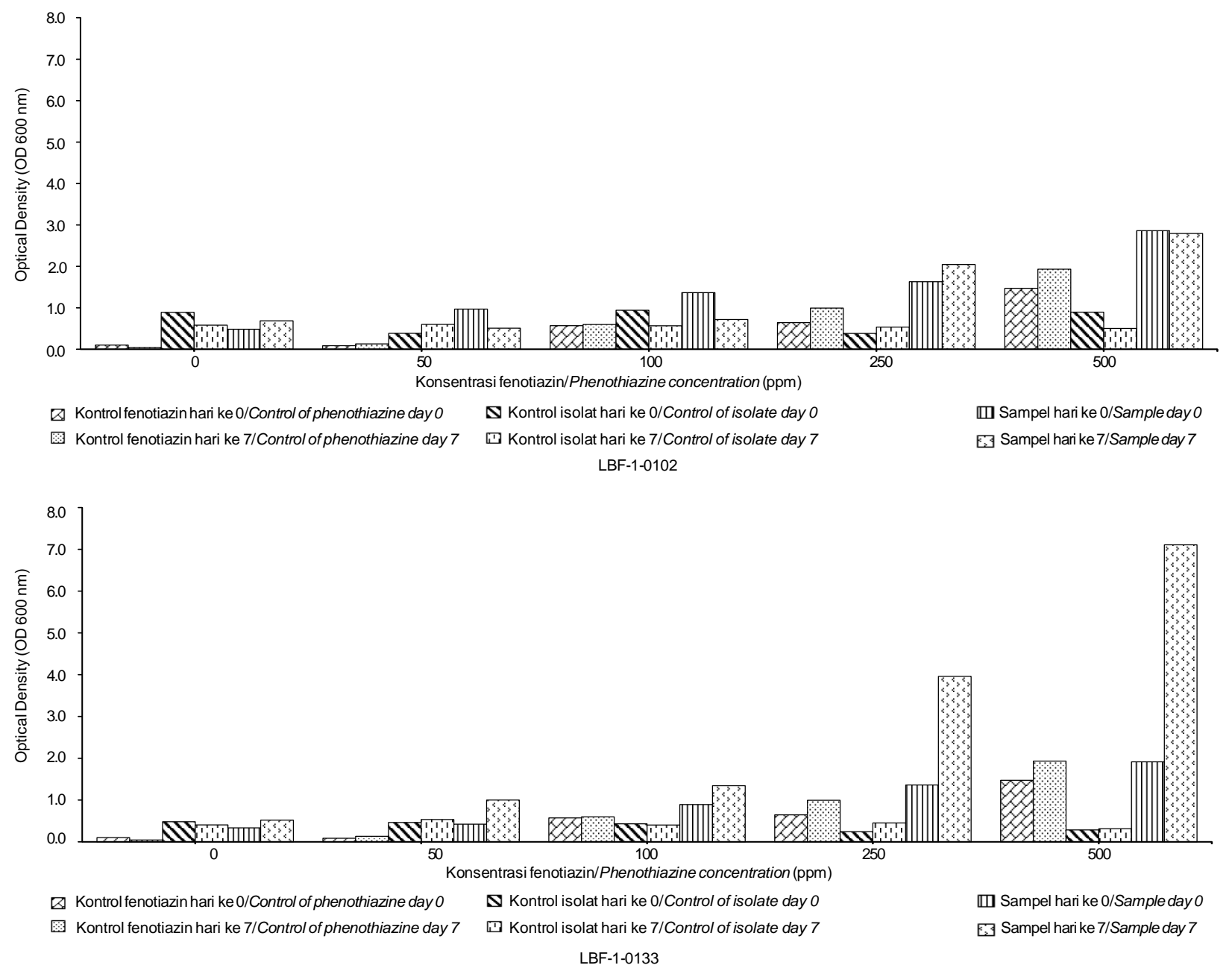

Gambar 6. Hasil optimasi konsentrasi fenotiazin dari 2 isolat terpilih dari kelompok yang mampu membentuk zona bening

Figure 6. Results of optimization of phenothiazine concentration 2 (two) selected isolates capable of forming clear zone

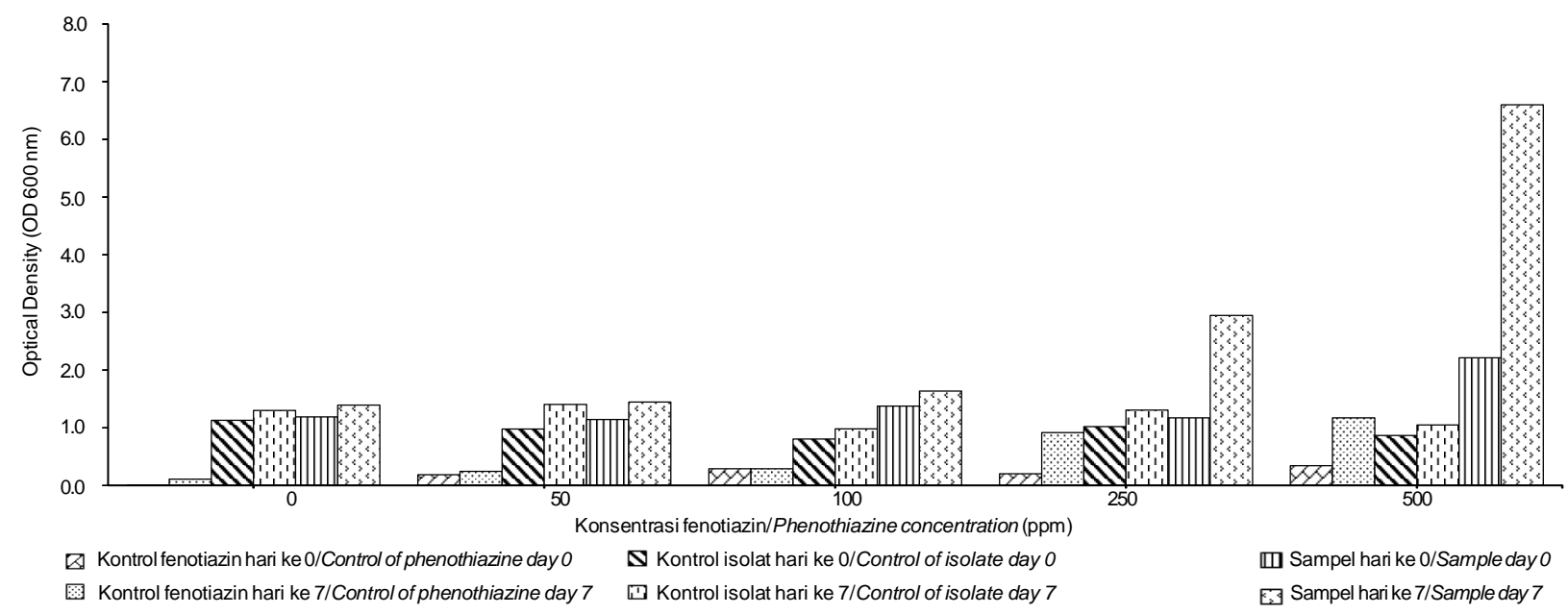

Gambar 7. Hasil optimasi konsentrasi fenotiazin isolat terpilih LBF-1-0115 dari kelompok yang mampu mengubah warna media dan membentuk zona bening

Figure 7. Results of optimization of phenothiazine concentration 1 (one) selected isolates capable of forming clear zone and changing medium colour 
menunjukkan indikasi yang berbeda. Isolat LBF-10102 dapat tumbuh optimal pada konsentrasi fenotiazin $250 \mathrm{ppm}$, sedangkan isolat LBF-1-0133 optimal tumbuh pada konsentrasi 500 ppm (Gambar 6).

Isolat LBF-1-0115 merupakan isolat potensial pendegradasi fenotiazin yang memiliki kemampuan mengubah warna media dan membentuk zona bening. Pada uji perumbuhan untuk optimasi konsentrasi fenotiazin terlihat bahwa isolat LBF-1-0115 optimal tumbuh pada konsentrasi 500 ppm (Gambar 7).

Hasil optimasi konsentrasi fenotiazin untuk pertumbuhan yang berbeda menunjukkan kemampuan isolat bakteri yang berbeda-beda dalam mengadaptasi lingkungan media yang mengandung fenotiazin. Isolat LBF-1-0057, LBF-1-00133, dan LBF-1-0115 merupakan isolat terbaik yang mewakili masing- masing kelompok. Isolat-isolat ini terlihat paling tinggi pertumbuhannya dan dapat mengkonsumsi fenotiazin hingga konsentrasi 500 ppm. Kemampuan mengkonsumsi substrat yang tinggi ini dapat digunakan sebagai dasar untuk menguji kemampuannya dalam mendegradasi senyawa fenotiazin pada konsentrasi yang tinggi dengan uji kuantitatif.

\section{Hasil Identifikasi Gen Parsial 16SRNA Bakteri dan Pohon Filogenik}

Hasil identifikasi isolat potensial sebagai hidrokarbonoklastik fenotiazin disajikan pada Gambar 8 dalam bentuk pohon kekerabatan. Isolat-isolat terpilih pendegradasi fenotiazin dari kelompok yang mengubah warna media yakni isolat LBF-1-0056 dan LBF-1-0057 teridentifikasi sebagai Pseudomonas

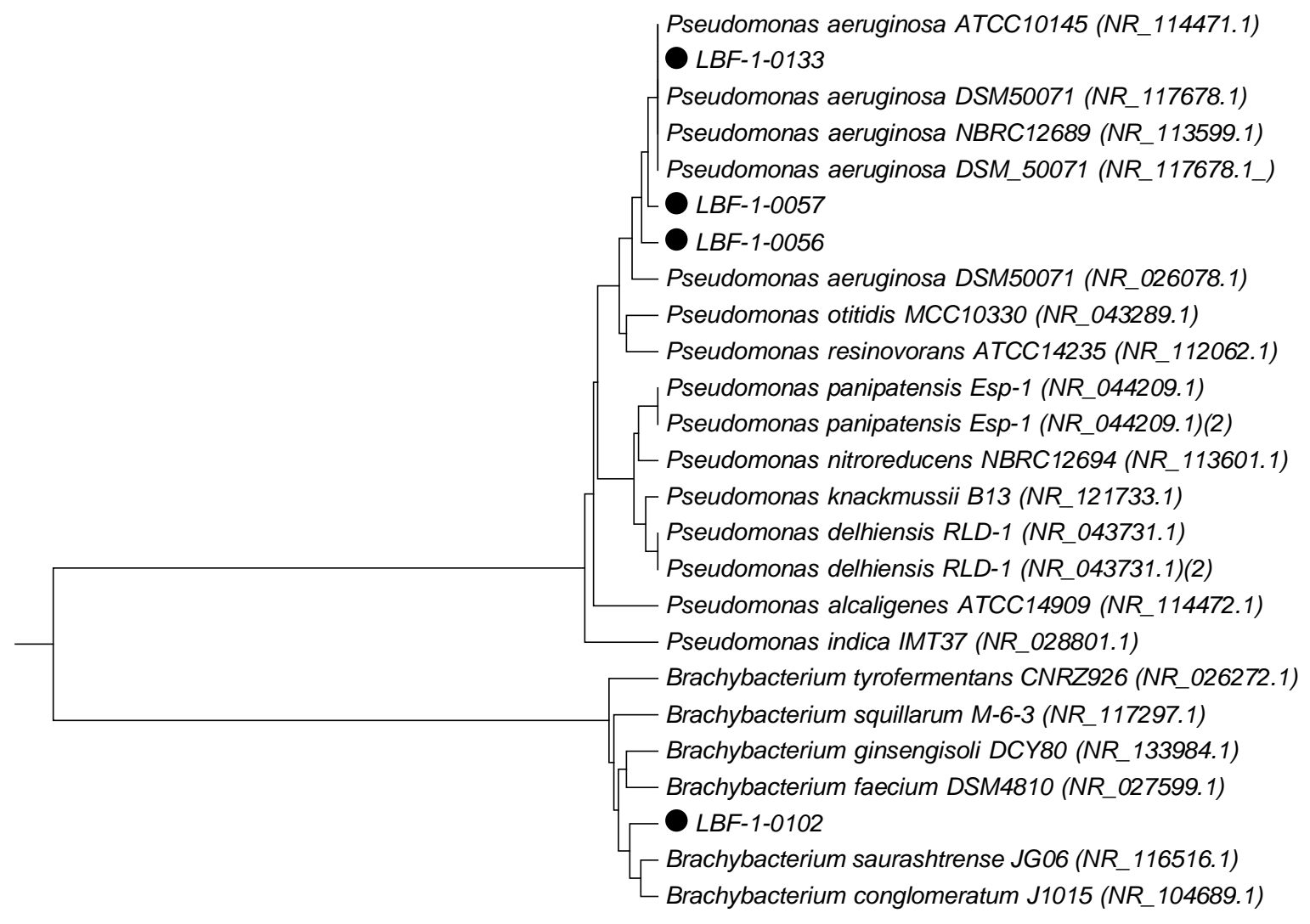

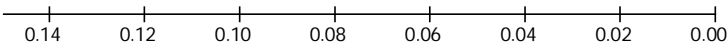

Gambar 8. Hubungan kekerabatan isolat berpotensi sebagai hidrokarbonoklastik fenotiazin digambarkan dengan pohon filogenik

Figure 8. Neighbour-joining relationship among potential phenothiazine hydrocarbonoclastic isolates illustrated by phylogenic tree 
aeruginosa MCCB102 dengan kemiripan masingmasing 98\%, sedangkan isolat LBF-1-0126 belum teridentifikasi. Hasil identifikasi terhadap kedua isolat tersebut sedikit berbeda dengan Yetti et al. (2016) yang mendapatkan spesies sama tetapi strain yang lain.

Identifikasi isolat dari kelompok yang membentuk zona bening menunjukkan bahwa LBF-1-0102 dan LBF-1-0133 memiliki kemiripan dengan Pseudomonas balerica BerOc6 (97\%) dan P. aeruginosa ATCC1045 (98\%). Hasil penelitian ini juga mendukung penelitian sebelumnya bahwa isolat LBF-1-0102 yang teridentifikasi sebagai $P$. balerica BerOc6 terseleksi sebagai bakteri pendegradasi senyawa $\mathrm{PAH}$ salah satunya fenotiazin (Yetti, Thontowi, Yopi \& Lisdiyanti, 2015). Sedangkan identifikasi ulang dalam penelitian ini terhadap isolat LBF-1-0133 juga berbeda dengan Yetti et al. (2016) yang mengidentikasinya sebagai Pseudomonas stutzeri strain W31. Hal ini dapat disebabkan oleh perbedaan kualitas DNA isolat yang diperoleh dan perkembangan bank data sekuen mikroorganisme yang berubah pada saat identifikasi isolat dilakukan.

Isolat LBF-1-0115 sebagai isolat dengan pertumbuhan paling baik di kelompok isolat dengan kemampuan dapat mengubah warna media dan membentuk zona bening belum terindentifikasi. Identifikasi yang dilakukan terhadap isolat potensial ini belum mendapatkan hasil kemiripan sekuen DNA dengan spesies bakteri tertentu. Hal ini kemungkinan karena DNA isolat yang diperoleh belum baik kualitasnya.

\section{KESIMPULAN}

Dari hasil penelitian ini kami menyimpulkan bahwa terdapat 6 isolat yang berpotensi sebagai hidrokarbonoklastik senyawa fenotiazin yang memiliki pertumbuhan paling baik di antara isolat lainnya. Isolatisolat tersebut teridentifikasi sebagai $P$. aeruginosa MCCB102 (2 isolat), P. balerica BerOc6 (1 isolat), dan $P$. aeruginosa ATCC1045 (1 isolat). Sedangkan 2 isolat lain belum teridentifikasi. Hasil optimasi konsentrasi optimum pertumbuhan dari isolat terpilih dalam penelitian ini merupakan acuan untuk studi biodegradasi fenotiazin selanjutnya. Studi biodegradasi lebih lanjut penting dilakukan untuk mengetahui kemampuan masing-masing isolat terpilih dalam mendegradasi senyawa fenotiazin.

\section{UCAPAN TERIMAKASIH}

Ucapan terimakasih penulis sampaikan kepada DIPA Tematik Puslit Bioteknologi LIPI 2016 dan
Proyek SATREPS Development of Internationally Standardized Microbial Resources Center as a Core of Biological Resources Center to Promote Life Science Research and Biotechnology 2011-2016 atas dukungan dana dalam pelaksanaan penelitian ini.

\section{DAFTAR PUSTAKA}

Demaneche, S., Meyer, C., Micoud, J., Louwagie, M., Willison, J. C., \& Jouanneau, Y. (2004). Identification and functional analysis of two aromaticringhydroxylating dioxygenases from a Sphingomonas strain that degrades various polycyclic aromatic hydrocarbons. App/ Environ Microbiol.,70(11), 6714-6725. doi: 10.1128/ AEM.70.11.6714-6725.2004

Eisler, R. (1987). Polycyclic Aromatic Hydrocarbons hazards to Fish, Wildlife, and Invertebrates : A Synoptic Review. U.S, Fish and Wildlife Service Biological Report 85 (1.11).

Francy, D. S., Thomas, J. M., Raymond, R. L., \& Ward, C. H. (1991). Emulsification of hydrocarbons by subsurface bacteria. J. Ind. Microbiol 8 (4), 234-246. Retrieved from https://pubs.er.usgs.gov/publication/ 70016515

Jaszczyszn, A., Gasiorowski, K., Sweater, P., Marina, W., Cieslik-Boczula, K., Petrus, J., \& Czarnik-Matusewicz, B. 2012. pharmacology Rep., 64 (1), 16-23. Retrieved from www.ncbi.nlm.nih.gov/pubmed /22580516

Haritash, A. \& Kaushik, C. (2009). Biodegradation aspects of Polycyclic Aromatic Hydrocarbons : A Review. Journal of Harzadous Materials , 169 (1-3),115. doi: 10.1016/j.jhazmat.2009.03.137. Epub 2009 Apr 7.

Hedlund, B. P., \& Staley, J.T. (2006). Isolation and characterization of Pseudoalteromonas strains with divergent Polycyclic Aromatic Hydrocarbon Catabolic Properties. Environ Microbiol 8 (1),178-82. doi:10.1111/j.1462-2920.2005.00871.x

Hedlund, B. P., \& Staley, J. T. (2001). Vibrio cyclotrophicussp. nov, a polycyclic aromatic hydrocarbon (PAH)-degrading marine bacterium. Int J Syst Evol Microbiol. 51, 61-66. Retrieved from http:/ / www.microbiologyresearch.org/ docserver/ fulltext/i jsem/ 51/ 1/ 0510061a.pdf.

Kastner, M., Breuer-Jammali, M., \& Mahro, B. (1994.) Enumeration and characterization of the soil microflora from hydrocarbon-contaminated soil sites able to mineralize polycyclic hydrocarbons (PAH). Appl. Microbiol. Biotechnol. 41 (2), 267-273. Retrieved from http://link.springer.com/article/ 10.1007/BF00186971.

Kiyohara, H., Nagao, K., \& Yana, K. (1982). Rapid screen for bacteria degrading water-insoluble, solid hydrocarbons on agar plates. Appl. Environ. Microbiol. 43 (2), 454-457. Print ISSN: 0099-2240, Online ISSN: 1098-5336PISrint ISSN: 0099-2240.

Lisdiyanti, P., Yopi., \& Murniasih, T. (2011). The Investigation of Polycyclic Aromatic Hydrocarbon and 
oil degrading bacteria isolated from the Marina Port Ancol, Jakarta Bay. Annales Bogoriences, 15 (2), 17-23.

Melcher, R. J., Apitz, S. E., \& Hemmingsen, B. B. (2002). Impact of irradiation and polycyclic aromatic hydrocarbon spiking on microbial populations in marine sediment for future aging and biodegradability studies. Appl Environ Microbiol., 68 (6), 2858-2868. doi: 10.1128/AEM.68.6.28582868.2002

Mrozik, A., Piotrwska-Seget, Z., \& Labuzek, S. (2003). Bacterial degradation and bioremediation of Polycyclic Aromatic Hydrocarbons. Polish Journal of Environmental Studies 12 (1), 15-25. Retrieved from http://www.pjoes.com/pdf/12.1/15-25.pdf

Pampanin, D. M., \& Sydnes, O. M. (2013). Polycyclic Aromatic Hydrocarbons : a Constituent of Petroleum : Presensce and Influence in the Aquatic Environtment. In Vladimir Kutcherov \& Anton Kolesnikov (Ed.). Physical and Theoretical Chemistry " "Hydrocarbon (pp. 83-118). Retrieved from http:// www.intechopen.com/ booksl

Stieber, M., Haeseler, F., Werner, P., \& Frimmel, F. H. (1994). A rapid screening method for microorganisms degrading polycyclic aromatic hydrocarbons. Appl. Microbiol. Biotechnol. 40 (5), 753 755. doi: 10.1007/BF00173340
Tanning, P.N., Yetti, E., Thontowi,A., Suprihadi, A., Purwantisari, S.,\& Yopi. 2016. karakterisasi Biodegradasi Senyawa Polarization Dibenzothiophene Oleh Bakteri Laut Novosphingobium mathurense LBF1-0061. Jurnal Biologi Indonesia, 12 (2), 257-264.

Thontowi, A., \& Yopi. (2013). Diversity of alkane and hydrocarbon degrading bacteria in Pari Island, Jakarta. Jurnal Biologi Indonesia, 9 (1), 137-146.

Wrenn, B. A., \& Venosa, A. D. (1996.) Selective enumeration of aromatic and aliphatic hydrocarbon degrading bacteria by a most-probable-number method. Can. J. Microbiol., 42 (3),252-258. Retrieved from https:// www.ncbi.nlm.nih.gov/ pubmed/ 8868232

Yetti, E., Thontowi, A., Yopi, \& Lisdiyanti P. (2015). Screening of Marine Bacteria Capable of Degrading Various Polyaromatic Hydrocarbons.Squalen Bull. of Mar. \& Fish. Postharvest \& Biotech., 10 (3), 121-127. Doi: http:// dx.doi.org/ 10.15578/ squalen. v10i3.123

Yetti, E., Thontowi, A., \& Yopi. (2016). Polycyclyc aromatic Hydrocarbon Degrading Bacteria from Several Indonesia Marine Area. Biodiversitas Journal, 17(2) 857-864. doi: 10.13057/biodiv/d170263

Yopi, Theresia, U. H., Thontowi, A., \& Susilaningsih, D. (2006). Characterization of Oil degrading Bacteria from Kamal Port, Jakarta Bay. Prosiding Seminar Nasional Bioteknologi. Cibinong, 15 -16 November 2006. ISBN 978-979-97789-3-2. 